\title{
RADIOCARBON DETERMINATION OF PAST GROWTH RATES OF LIVING ACACIA TORTILIS TREES FROM TWO ARID SITES IN THE EASTERN SAHARA
}

\author{
Tomasz Goslar ${ }^{1,2}$ • Gidske Andersen ${ }^{3}$ Knut Krzywinski ${ }^{3,4}$ • Justyna Czernik ${ }^{2}$ \\ ABSTRACT. Reconstructions are presented of past growth rates of 10 Acacia tortilis trees, 5 growing at an arid site (Gebeit, \\ Sudan) and 5 at a hyperarid site (Wadi Nuqrus, Egypt). The reconstructions were made using a free-shape age-depth model \\ based on a series of ${ }^{14} \mathrm{C}$ dates obtained on samples taken along the wood cores retrieved from the trunks of the trees (78 dates \\ in total). In spite of the large difference in annual precipitation between the 2 sites, the range of ages of the trees (60-350 yr) \\ and the variability in their growth rates are quite similar across both sites, whereas within-site growth rates are quite different \\ even for closely spaced individuals. However, the pattern of growth rates of Acacias from the hyperarid Wadi Nuqrus indi- \\ cates 2 periods of different aridity (the less arid AD 1650-1780 and more arid AD 1780-1930), while at Gebeit no such pat- \\ tern has been detected.
}

\section{INTRODUCTION}

This article presents radiocarbon dates from cores of trunks of living Acacia tortilis (Forssk.) Hayne trees, and probable models of their past growth. The trees were sampled in Gebeit (Red Sea State, Sudan) and Wadi Nuqrus (Eastern Desert, Egypt) and are studied within the framework of "Climate history and long-term dynamics of tree populations" of the ACACIA Project, ${ }^{5}$ one of the goals of which is to discover whether or not stable $\mathrm{O}$ and $\mathrm{C}$ isotopes from A. tortilis wood in this region can serve as meteorological proxies in areas and periods for which historical climatic records are lacking. Previous findings suggest that $A$. tortilis individuals are relatively long lived (Andersen and Krzywinski 2007a) and constitute the only widespread arboreal species growing across North Africa and the Middle East. If stable $\mathrm{O}$ and $\mathrm{C}$ isotope fractions in wood cellulose contain climate proxies, this will provide valuable and needed information about an area where past and future climate scenarios and their effects are highly uncertain.

Acacia tortilis is the dominant species in the mountainous landscape of the Red Sea Hills (RSH) of the eastern Sahara. It grows in the seasonally dry river valleys (wadis) intersecting the mountains (Andersen 2012). Rainfall and the resulting surface water and moisture in the upper part of the soil are highly unreliable, so during long, dry periods between rains the species depends mainly on the more constant and reliable moisture from deeper soil layers (Kassas and Imam 1954) that seeps downstream through subsurface layers.

In addition to soil moisture, the growth of Acacia trees is mainly influenced by branch cutting, i.e. lopping and pollarding, and by browsing by wild and domesticated animals. In the RSH, nomadic pastoralists have tended trees for as long as several millennia (Krzywinski and Pierce 2001; Andersen 2012). Until recently, all mature trees were pollarded at varying intervals and with varying intensity. At high intensity, all green biomass is removed and consequently growth stops temporarily; at high frequency, growth becomes very slow. The motivation for pollarding is the feeding of domestic animals and/or renewal of the tree, the latter performed in cases where trees are drying out. Since trees constitute the only reliable source of fodder during dry periods, the degree and intensity of lop-

\footnotetext{
${ }^{1}$ Faculty of Physics, A. Mickiewicz University, Umultowska 85, 61-614 Poznań, Poland. Corresponding author. Email: tomasz.goslar@radiocarbon.pl.

${ }^{2}$ Poznań Radiocarbon Laboratory, Rubież 46, 61-612 Poznań, Poland.

${ }^{3}$ Uni Research AS, P.O. Box 7810, 5020 Bergen, Norway.

${ }^{4}$ Department of Biology, University of Bergen, P.O. Box 7800, 5020 Bergen, Norway.

5 "Interactions among human interference, climate and the viability and dynamics of contracted acacia populations in the Eastern Sahara” (http://desert.cultland.org/uploads/files/file_000039.pdf).
}

(C) 2013 by the Arizona Board of Regents on behalf of the University of Arizona Proceedings of the 21st International Radiocarbon Conference edited by A J T Jull \& C Hatté RADIOCARBON, Vol 55, Nr 2-3, 2013, p 1683-1692 


\section{T Goslar et al.}

ping and pollarding may vary considerably in time and space. The shapes of the trees in general and in particular the sizes of their crowns are therefore a product of past and present management regimes. Stopping pollarding might at first increase crown growth, but local informants claim that over time mortality among formerly pollarded trees is higher than that among trees still being pollarded (ACACIA, unpublished data). High browsing pressure over a longer period may also significantly retard growth, particularly in young trees (Martin and Moss 1997). Mammalian herbivores may, however, promote recruitment of Acacias in many ways (Rohner and Ward 1999; Or and Ward 2003).

In the area of interest, $A$. tortilis does not form visible annual tree rings, but bands of calcium oxalate crystals occur at irregular intervals (Gourlay 1995; Andersen and Krzywinski 2007a). How long A. tortilis trees can live has thus been a matter of debate, with local opinions in this area ranging from very long (>1000 yr; Hobbs 1989) to very short in comparable environments (Ward and Rohner 1997). Based on ${ }^{14} \mathrm{C}$ dating, a first insight into the actual lifespans and growth rates of $A$. tortilis trees growing under arid to hyperarid conditions revealed probable ages of older individuals of around 300-400 yr (Andersen and Krzywinski 2007a). In this study, we attempt to corroborate lifespan estimates and to construct past growth rates at a finer temporal resolution, based on a larger set of ${ }^{14} \mathrm{C}$ dates (78) from a larger sample of trees (10) reflecting 2 different aridity regimes. Age and growth curves are modeled using the algorithm of free-shape age-depth modeling (Goslar et al. 2009) on the basis of ${ }^{14} \mathrm{C}$ dates of up to 15 samples from across the length of each wood core.

\section{STUDY SITES}

Gebeit $\left(18.96^{\circ} \mathrm{N}, 36.84^{\circ} \mathrm{E}\right)$ is presently a small town $\sim 50 \mathrm{~km}$ inland from the Red Sea coast of Sudan (Figure 1). It has one of the few meteorological stations in the area of interest with a long rainfall record, starting in 1908 (Vose et al. 1992). Average annual precipitation is 100 mm, but differences from year to year are large as indicated by a coefficient of variation (1949-1979; CV) of 68\% (e.g. $>300 \mathrm{~mm}$ in AD 1959 and $<10 \mathrm{~mm}$ in 1973). The Gebeit locality is situated close to the town in a wider part ( $\sim 2 \mathrm{~km})$ of the wadi. Acacia trees in Gebeit grow separately or in stands of several individuals, and the population has been reduced by charcoaling during the last decennia. Two subspecies of $A$. tortilis, i.e. ssp. raddiana and ssp. tortilis, grow there.

Wadi Nuqrus $\left(\sim 24.62^{\circ} \mathrm{N}, 34.78^{\circ} \mathrm{E}\right)$ is located in the hyperarid Eastern Desert of Egypt. It has no direct meteorological records, and the closest meteorological stations (several hundred km away) record very rare rains, with no precipitation in about half of the monitored years. Annual precipitation in the wettest years barely exceeds $60 \mathrm{~mm}$, and the CV (1973-1990) is 200\% for the 4 closest stations (Figure 1; Andersen 1999; Krzywinski and Pierce 2001). The general geographic setting of this site is in many ways comparable to that in Gebeit, but with a narrower wadi, a smaller catchment, and higher aridity; and A. tortilis individuals (ssp. raddiana only) grow more widely separated. The population is negatively affected by charcoal production (Andersen and Krzywinski 2007b), but less intensively than at Gebeit.

\section{MATERIAL AND METHODS}

At each of the sites studied, wood cores (13 mm in diameter and 150-350 mm long) were retrieved from the trunks of 5 living trees $\sim 50 \mathrm{~cm}$ above ground (Figure 1). Only mature trees were sampled (Table 1) and only among the larger and presumably oldest individuals. All Nuqrus samples were collected in February/March 2003, while Gebeit cores were sampled in September 2010. A total of 78 samples from these 10 cores were submitted for ${ }^{14} \mathrm{C}$ dating to satisfy the requirements for optimizing the calendar chronologies of the cores. ${ }^{14} \mathrm{C}$ measurements in these samples were performed 


\section{Growth Rates of Living Acacia tortilis, Eastern Sahara}

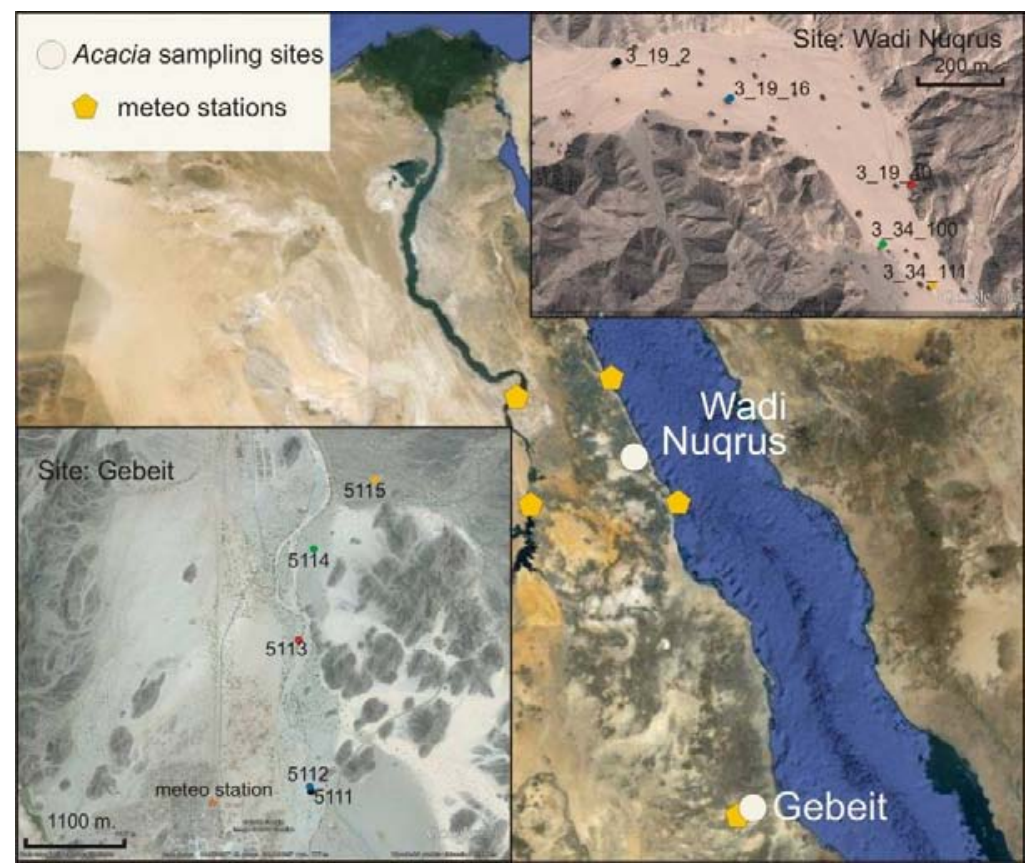

Figure 1 Location of the sites (Gebeit in Sudan and Wadi Nuqrus in Egypt) sampled in the present study. In the insets, locations of the individual trees sampled are shown.

on alpha-cellulose extracted from wood (Nemec et al. 2010). Results (Table 2) revealed post-bomb ${ }^{14} \mathrm{C}$ concentrations (Hua and Barbetti 2004; Levin et al. 2010) in the outer parts of the tree trunks, while the inner parts almost exclusively yielded ${ }^{14} \mathrm{C}$ dates between $\sim 100$ and $200{ }^{14} \mathrm{C} \mathrm{BP}$, in agreement with the range of the wiggly part of the ${ }^{14} \mathrm{C}$ calibration curve between $\mathrm{AD} 1650$ and 1950 (Reimer et al. 2009). Based on the ${ }^{14} \mathrm{C}$ data, calendar chronologies of individual cores were constructed (Figure 2) using the algorithm of free-shape age-depth modeling (Goslar et al. 2009). All ${ }^{14} \mathrm{C}$ dates of wood formed just before the bomb period (Figure 2) fit the calibration curve very well. These results confirm that mobile organic compounds, e.g. sap transporting ${ }^{14} \mathrm{C}$-enriched carbon from the younger parts of the trunk, are effectively removed in the procedure of cellulose extraction.

Table 1 Measurements of the Acacia tortilis trees analyzed in the present study. Gebeit trees were measured and sampled in 2010. Nuqrus trees were sampled in 2003. * indicates measures taken in 2003, and ** measures (except trunk diameter) taken in 1996.

\begin{tabular}{llllllc}
\hline & $\begin{array}{l}\text { Height } \\
(\mathrm{m})\end{array}$ & $\begin{array}{l}\text { Lower } \\
\text { canopy } \\
\text { height }(\mathrm{m})\end{array}$ & $\begin{array}{l}\text { Nr of } \\
\text { trunks } \\
\text { at base }\end{array}$ & $\begin{array}{l}\text { Nr of trunks at } \\
\text { breast height }\end{array}$ & $\begin{array}{l}\text { Largest trunk } \\
\text { diameter }(\mathrm{cm})\end{array}$ & $\begin{array}{l}\text { Canopy } \\
\text { diameter } \\
(\mathrm{m})\end{array}$ \\
\hline Gebeit 5111 & 6.7 & 3.4 & 1 & 2 & 46.3 & 13.2 \\
Gebeit 5112 & 7.5 & 4.2 & 1 & 1 & 41.7 & 11.8 \\
Gebeit 5113 & 5.8 & 2.6 & 1 & 3 & 27.8 & 12.1 \\
Gebeit 5114 & 5.4 & 2.8 & 1 & 2 & 44.3 & 13.0 \\
Gebeit 5115 & 5.7 & 3.8 & 1 & 1 & 31.0 & 9.0 \\
\hline Nuqrus 19-2* & 11.5 & 3.0 & 1 & 1 & 66 & 19.0 \\
Nuqrus 19-16* & 14.5 & 4.0 & 1 & 1 & 69 & 16.2 \\
Nuqrus 19-40* & 13.5 & 2.5 & 1 & 1 & 59 & 13.3 \\
Nuqrus 34-100** & $\sim 7.5-8$ & 2.5 & 1 & 1 & 51 & $\sim 13.3$ \\
Nuqrus 34-111** & $\sim 6.5$ & 2.0 & 2 & 2 & 50 & $\sim 9.3$ \\
\hline
\end{tabular}


T Goslar et al.

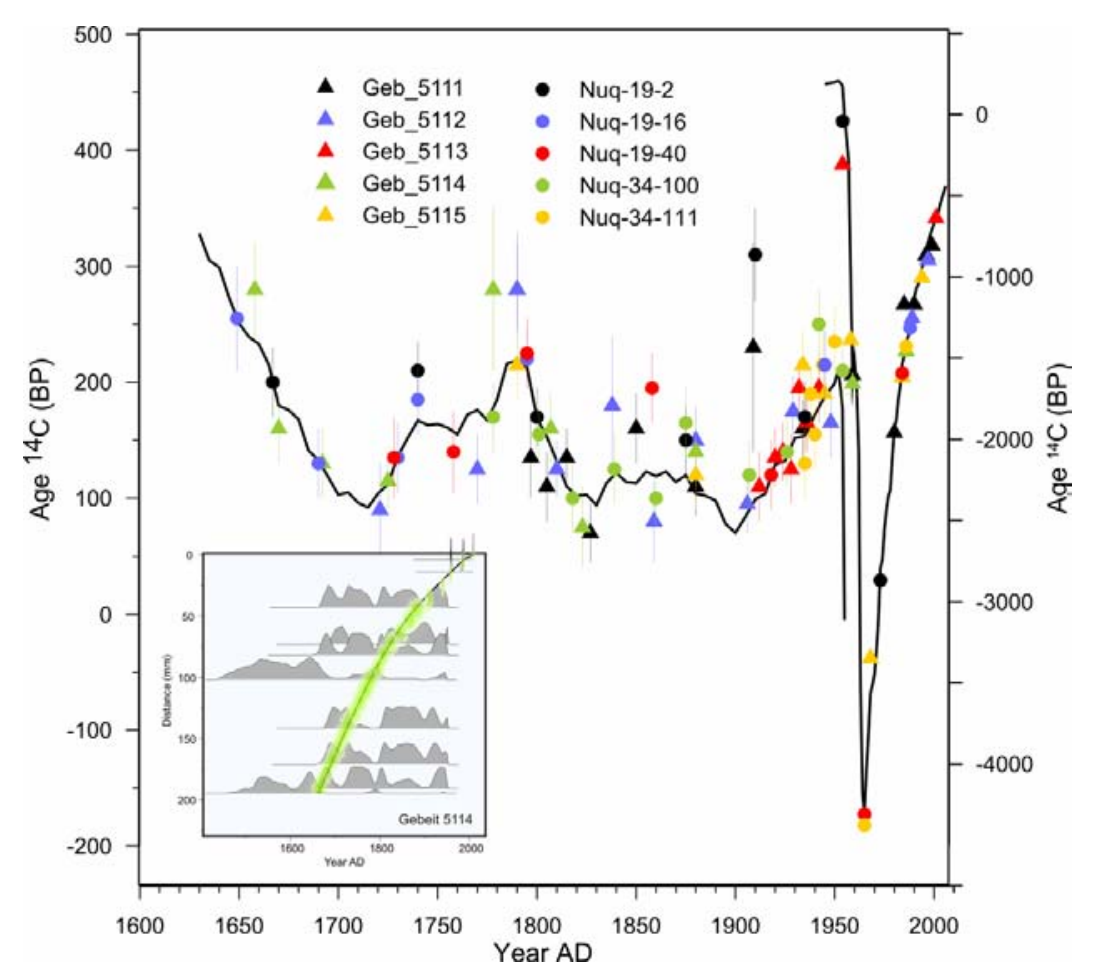

Figure $2{ }^{14} \mathrm{C}$ ages of the wood samples from the Acacia tortilis trees analyzed in the present study, presented on the background of the ${ }^{14} \mathrm{C}$ calibration curve. Calendar dates of individual samples were determined by the age-distance models, as described in the text. Note: vertical scale (Age ${ }^{14} \mathrm{C}$ ) on the left-hand side, concerns ${ }^{14} \mathrm{C}$ ages and calibration curves in the pre-bomb period (until AD 1950), while the scale on the right-hand side concerns ${ }^{14} \mathrm{C}$ ages in the post-bomb period (between 1950-2010). The inset illustrates the age-distance model of one selected tree (Gebeit 5114). Probability distributions of calibrated ${ }^{14} \mathrm{C}$ ages of individual samples are shown by gray silhouettes, while the model is represented by a green band.

\section{RESULTS: GROWTH RATES OF THE ANALYZED TREES}

Most individual calibrated ${ }^{14} \mathrm{C}$ dates placed the possible ages of samples within very wide intervals between about $\mathrm{AD} 1650$ and 1950, reflecting the wiggly shape of the ${ }^{14} \mathrm{C}$ calibration curve. Even so, dating sequences of between 7 and 15 samples from each core (Table 2) enabled us to construct rather accurate age-distance models and to find distinct differences between the ages and past growth rates of individual trees (Figures 3a and 3b).

\section{Gebeit Site}

The analyzed trees from Gebeit (Figure 3a) appeared to be 100-350 yr old. The oldest one, Gebeit 5114, grew rather slowly ( $210 \mathrm{~mm}$ in $350 \mathrm{yr}$ ), and since about AD 1850 its growth rate has been the slowest of all the analyzed trees. Gebeit 5111 is the thickest and fastest growing tree $(330 \mathrm{~mm}$ in $220 \mathrm{yr}$ ). At the time of sampling, it had the best-developed, round crown of all the trees analyzed at this site. Together with 5112, it grows at the edge of the main water channel, the khor, of the wadi. Gebeit 5111 has a well-developed canopy and a special ritual status: local people place the placentas of male children in its canopy as a sacrifice. How long the tree has enjoyed this status and to what degree this practice secures it any protection is not known. After about AD 1930, Gebeit 5115, with 
Growth Rates of Living Acacia tortilis, Eastern Sahara
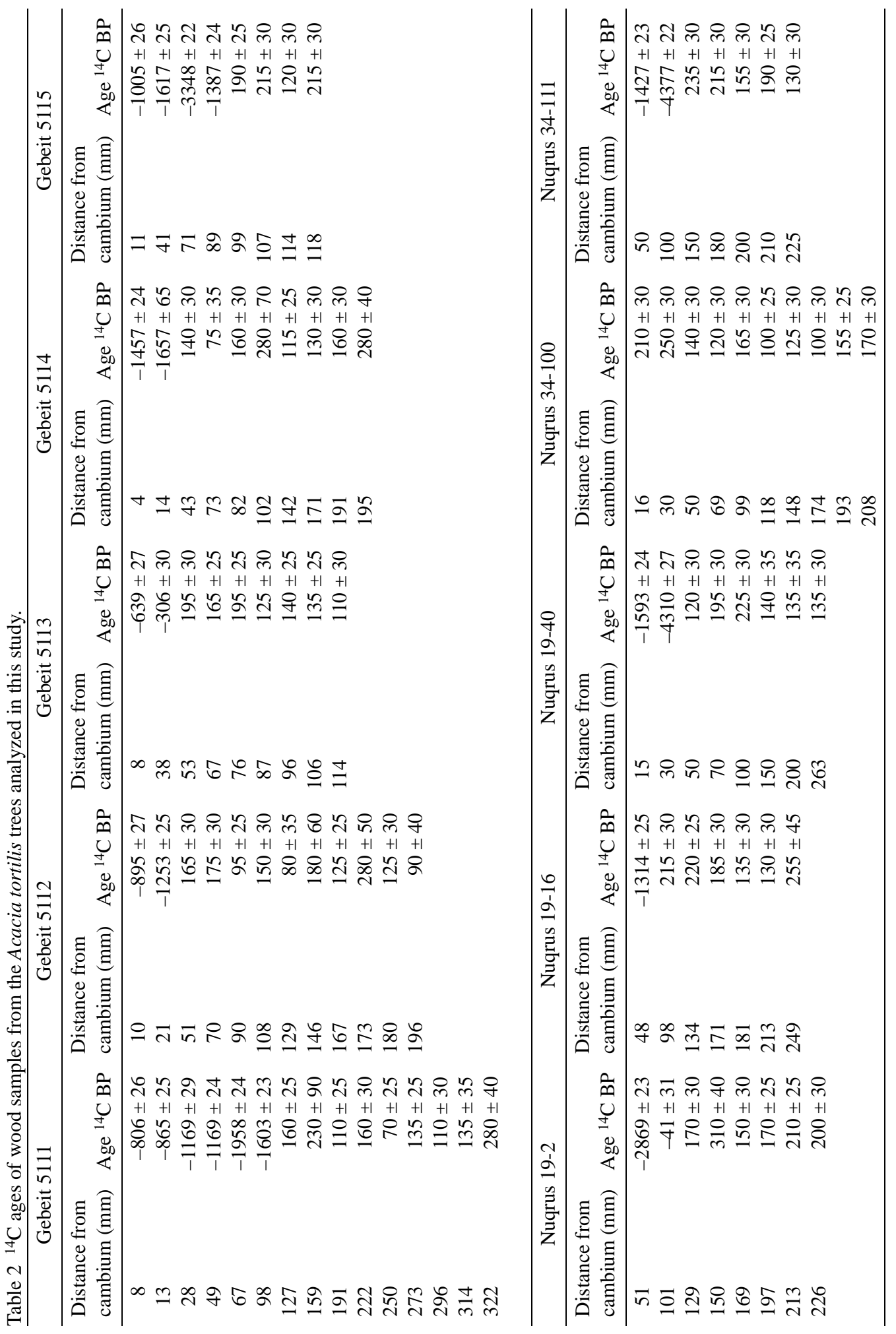


\section{T Goslar et al.}
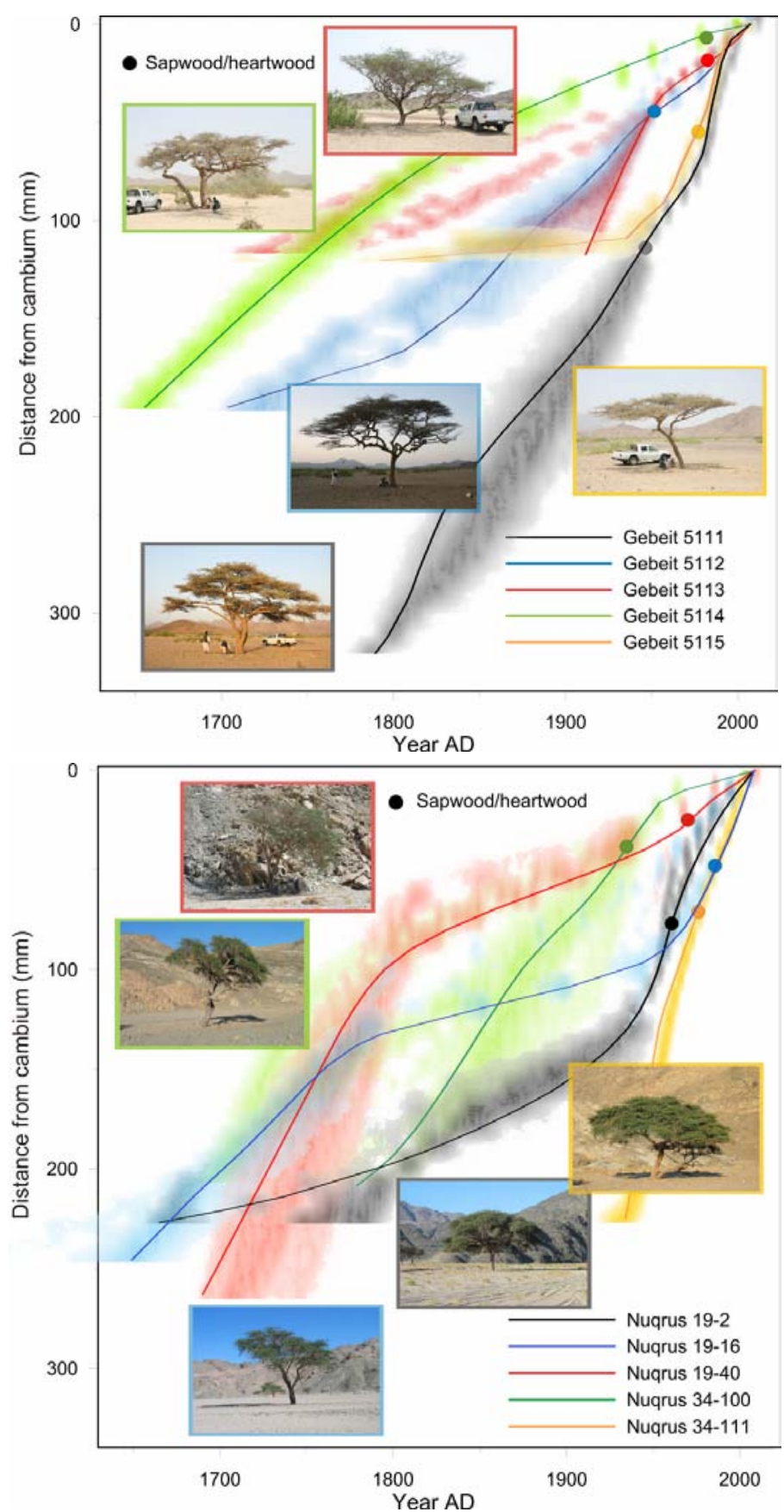

Figure 3 Age-distance models of the Acacia tortilis trees from the site Gebeit (a, top) and Wadi Nuqrus (b, below). Distance from cambium of trunk was measured along the cores drilled from the trunks of individual trees. Solid lines represent the best-fit models, while the colored bands represent uncertainties of the models. Colors of frames around the photographs correspond to the particular trees studied. Positions of sapwood/heartwood boundaries in the individual trees are marked by circles. 


\section{Growth Rates of Living Acacia tortilis, Eastern Sahara}

its much thinner trunk and flat, wide crown, grew as fast as Gebeit 5111 (110 mm in $80 \mathrm{yr})$. The growth duration of the innermost $20 \mathrm{~mm}$ (between 130 and $110 \mathrm{~mm}$ ) of this tree is, however, modeled very imprecisely (between 250 and $15 \mathrm{yr}$ !) because there are only $4{ }^{14} \mathrm{C}$ dates from the prebomb period, and their pattern did not give a clear fit to the wiggles of the calibration curve. Until about AD 1800, Gebeit 5112 grew more slowly than it did during the last 200 yr (average growth rate of $210 \mathrm{~mm}$ in $300 \mathrm{yr}$ ). Gebeit 5113 grew about as fast as Gebeit 5112 after about AD 1950, but its growth rate before AD 1950 is determined very imprecisely ( $80 \mathrm{~mm}$ in a period of 30-240 yr).

\section{Wadi Nuqrus Site}

The range of trees' ages in Wadi Nuqrus (Figure 3b) is between 80 and 350 yr. Despite there having been much less precipitation in Wadi Nuqrus, Acacia trees there are taller (Table 1) and their trunks have the same variability in growth rate as those in Gebeit. The youngest and fastest growing tree is Nuqrus 34-111 (220 mm in 80 yr). Nuqrus 19-2 had a similar fast growth after about AD 1930, before which it grew much more slowly than Nuqrus 34-111. Nuqrus 34-100 had a moderate growth rate until about AD 1950, but an exceptionally slow one in the last decades. The sapwood/heartwood boundary of this tree is also extremely old ( $75 \mathrm{yr})$. Nuqrus 19-40 and 19-16 grew relatively fast up to about AD 1800, then slowed down until around 1950, and grew faster again during recent decades. One must point out, however, that except during the 18th century AD, Nuqrus 19-40 (situated at the edge of the wadi) had on average the slowest growth rate of all the trees analyzed.

\section{DISCUSSION}

The growth rate and calendar chronologies we present are based on an algorithm of free-shape agedepth modeling (Goslar et al. 2009). This model assumes that growth rates may change over the lifespan of the trees, but that these changes will be gradual rather than sudden. There are few if any ways to test this assumption for the wiggle period AD $1650-1950$. The ${ }^{14} \mathrm{C}$ dates of the wood formed during the bomb period (Figure 2) do, however, fit the calibration curve well and do not indicate abrupt changes in growth. During the post-war period, the region experienced several climatic fluctuations, including the Sahel drought (1968-1973), but these do not seem to have influenced growth in a way that contradicts the assumptions of our model.

Several interesting points are suggested by our results. All the individuals studied were mature trees with a lifespan of up to $350 \mathrm{yr}$. It is important to note that none of the trees sampled had a ${ }^{14} \mathrm{C}$ content confirming ages older than the wiggly part of the curve, i.e. older than AD 1650. Longevity of up to $350 \mathrm{yr}$ in this study corroborates the ages suggested by Andersen and Krzywinski (2007a). It is also worth noting that overall growth rates are slow but within a similar range at both sites studied in spite of the large differences in aridity regime and annual precipitation (mean in Nuqrus $<20 \mathrm{~mm}$ and CV $200 \%$, mean in Gebeit $\sim 100 \mathrm{~mm}$ and CV 68\%).

Despite the general picture of old age and slow growth, the shape of the reconstructed temporal growth curves clearly suggests that these trees had individual growth patterns over time. It has been suggested that the shape of the growth curve of such trees is best represented by a sigmoidal Gompertz growth model (Zeide 1993; Andersen and Krzywinski 2007a), but our models do not conform to any previously proposed growth curve. Only Nuqrus 19-2 has a shape somewhat similar to the sigmoidal Gompertz curve. Of the least uncertain models at Gebeit, 5114 has a smooth and slightly concave shape, while the overall shapes of 5111 and 5112 give a linear impression from about the 1830 s to the 1970s. Such a linear impression also holds true for 34-111 and 34-100, although the latter is quite uncertain prior to the 1850s. The 2 remaining trees at Nuqrus, 19-40 and 19-16, also have growth curves of similar shape (fast, slower, and then faster growth again). 


\section{T Goslar et al.}

Variation in the growth curves means that at any given time, growth varies both within the lifespan of the individual trees and among trees. A closer look at the past $50 \mathrm{yr}$ at Gebeit, i.e. the period of the ${ }^{14} \mathrm{C}$ bomb-peak, which provides the most accurate age models, reveals that the pair of trees Gebeit 5111 and 5115 had the faster growth rates (i.e. 1.8-2 mm/yr), that the pair Gebeit 5112-5113 had a much slower growth rate (i.e. 0.6-0.8 mm/yr), and that the tree Gebeit 5114 had an even slower rate (i.e. $\sim 0.4 \mathrm{~mm} / \mathrm{yr}$ ). Inspection also shows that the 2 closest trees, 5111 and 5112, had quite different growth rates, while the 2 most distant trees, 5111 and 5115, had identical growth rates, which suggests that complex and spatially uncorrelated factors may govern growth of these trees. This is also in line with previous findings based on comparison of patterns of calcium oxalate bands (Andersen and Krzywinski 2007a). Nevertheless, it is worth noting, as mentioned above, that the growth rates of 5111 and 5112 are nearly linear and quite similar over an extended period from about the 1830s to the 1970s. If we look at the last $30 \mathrm{yr}$ for Nuqrus, differences in growth rates are evident (between 0.3-3 mm/yr), except for 19-16 and 34-111, which have experienced nearly identical growth rates (i.e. $\sim 3 \mathrm{~mm} / \mathrm{yr}$ ) since about the 1960s. Again, this is among the most widely separated pairs of sampled trees, but both have a similarly central location in the wadi cross-section.

Originally, we expected to see only a small variation in growth rates within the relatively small sites sampled and a larger one between them. This is not the case. Small-scale variation due to geological features such as dikes may cause within-site soil moisture variations, but the fact that the range of growth rates is similar between the 2 sites studied (across the aridity gradient) suggests that other factors besides soil moisture are significant. The only other factor we know of that might influence growth is variation in management practices. It might be argued that how trees are tended within a smaller area should also be constant over time. The known ownership structure and usufruct rights in trees indicate that smaller family groups tend trees in a limited area, and one might argue that how individual trees are tended during a given period should be similar and over longer time periods constant. Assuming, however, that differences in growth rates are due to tending practices implies that local people treat individual trees differently over longer periods of time. If this is so, then the varying influence of tending practices on individual trees might mask the general picture of the growth conditions at each site. There are, however, some apparent patterns in establishment and growth rate. Four of the 5 analyzed trees in Nuqrus were established between AD 1650 and 1780, whereas none of the analyzed trees was established between AD 1780 and 1930. Moreover, Nuqrus 19-40 and 19-16 grew faster before $\sim 1780$ than after.

Rainfall and surface moisture are the limiting factors for seed germination. Successful recruitment seems to require several consecutive rainfall events (unpublished ACACIA interview data; Wiegand et al. 2004). The fact that 4 of 5 trees at Nuqrus were established in a limited period might be due to how the sampled trees were selected, but might just as well indicate that the Nuqrus catchment had received more frequent rains during the time of establishment than later. If so, one might conclude that young Acacia trees established between AD 1650 and 1780 received rains frequently enough to develop roots that reached moist subsurface aquifers. This could have enabled them to survive dry spells during the more arid period between AD 1780 and 1930. Perhaps fewer Acacias had a chance to develop deep roots and grow up during this more arid period. No such pattern is, however, visible at Gebeit where conditions were generally less arid, indicating that climate at this site may not have been the most important factor limiting establishment and growth.

In addition to information about establishment, growth rate, and lifespan, the modeling approach also indicates the age of the sapwood-heartwood boundary. Despite quite different age and growth rates, the ages of sapwood/heartwood boundaries in the 2 closely placed trees at Gebeit (5111 and 5112, Figure 1) are similar (55-65 yr, Figure 3a). The ages of these boundaries in the other 3 trees 


\section{Growth Rates of Living Acacia tortilis, Eastern Sahara}

are distinctly younger, but also similar to one another (25-35 yr). In contrast to Gebeit, the ages of sapwood/heartwood boundaries at Nuqrus differ from one tree to another (45, 25, 40, 75, and $35 \mathrm{yr}$ ). How this observation should be interpreted is still under consideration.

\section{CONCLUSION}

Detailed ${ }^{14} \mathrm{C}$ dating of 10 Acacia tortilis trees from 2 sites in the Red Sea Hills, eastern Sahara, determined their ages to be between 350 and $60 \mathrm{yr}$. This confirmed the findings of Andersen and Krzywinski (2007a), who, on the basis of actual data, were the first to challenge the local opinions that favored an extremely long lifetime for this species in the region. In spite of a big difference in annual precipitation between the 2 sites studied (Gebeit, Wadi Nuqrus), the lifespans and growth rates lie within similar ranges. Within-site growth appears to be quite different even for closely placed individuals, and we argue that this is related to how these trees were tended. There is, however, a common pattern of growth rates of $A$. tortilis individuals from the hyperarid Wadi Nuqrus site that suggests there were 2 periods of different growth (AD 1650-1780 and 1780-1930), while at Gebeit no such pattern is detected.

There is a complex interaction between growth, water/soil moisture conditions, management, and climate. In particular, the effect of pollarding is difficult to factor. Combining the age-depth models with results from stable $\mathrm{C}$ and $\mathrm{O}$ isotope analysis, patterns of calcium oxalate bands and topo-hydrological parameters will probably help to disentangle the interaction among growth rate, water conditions, and management strategies.

\section{ACKNOWLEDGMENTS}

The project is funded by the Norwegian Research Council (\#196078) and "Olaf Grolle Olsen og Miranda Bødtkers legat.”

\section{REFERENCES}

Andersen GL. 1999. Change and variation in a hyper-arid cultural landscape: a methodological approach using remote sensing timeseries (LANDSAT MSS and TM, 1973-1996) from the wadi vegetation of the Eastern Desert of Egypt [thesis]. University of Bergen/ NERSC, Bergen.

Andersen GL, Krzywinski K. 2007a. Longevity and growth of Acacia tortilis: insights from ${ }^{14} \mathrm{C}$ content and anatomy of wood. BMC Ecology 7(4): doi: 10.11861472-6785-7-4.

Andersen GL, Krzywinski K. 2007b. Mortality, recruitment and change of desert tree populations in a hyperarid environment. PLoS ONE 2(2): e208, doi: 10.1371/journal.pone.0000208.

Andersen GL. 2012. Vegetation and management regime continuity in the cultural landscape of the eastern desert. In: Barnard H, Duistermaat $\mathrm{K}$, editors. The History of the Peoples of the Eastern Desert. Los Angeles: Cotsen Institute of Archaeology. p 126-39.

Goslar T, van der Knaap WO, van Leeuwen J, Kamenik Ch. 2009. Free-shape ${ }^{14} \mathrm{C}$ age-depth modelling of an intensively dated modern peat profile. Journal of Quaternary Science 24(5):481-99.

Gourlay ID. 1995. The definition of seasonal growth zones in some African Acacia species - a review. IAWA Journal 16(4):353-9.

Hobbs JJ. 1989. Bedouin Life in the Egyptian Wilderness. Austin: University of Texas Press.

Hua Q, Barbetti M. 2004. Review of tropospheric bomb radiocarbon data for carbon cycle modeling and age calibration purposes. Radiocarbon 46(3):1273-98.

Kassas M, Imam M. 1954. Habitat and plant communities in the Egyptian desert III. The wadi bed ecosystem. Journal of Ecology 42(2):424-45.

Krzywinski K, Pierce RH, editors. 2001. Deserting the Desert: A Threatened Cultural Landscape Between the Nile and the Sea. Bergen: Alvheim og Eide Akademisk Forlag.

Levin I, Naegler T, Kromer B, Diehl M, Francey RJ, Gomez-Pelaez AJ, Steele LP, Wagenbach D, Weller R, Worthy DE. 2010. Observations and modelling of the global distribution and long-term trend of atmospheric ${ }^{14} \mathrm{CO}_{2}$. Tellus B 62(1):26-46.

Martin D, Moss J. 1997. Age determination of Acacia tortilis (Forsk.) Hayne from northern Kenya. African Journal of Ecology 35(3):266-77.

Nemec M, Wacker L, Hajdas I, Gäggeler H. 2010. Alternative methods for cellulose preparation for AMS 


\section{T Goslar et al.}

measurement. Radiocarbon 52(3):1358-70.

Or K, Ward D. 2003. Three-way interactions between Acacia, large mammalian herbivores and bruchid beetles - a review. African Journal of Ecology 41(3):25765.

Reimer PJ, Baillie MGL, Bard E, Bayliss A, Beck JW, Blackwell PG, Bronk Ramsey C, Buck CE, Burr GS, Edwards RL, Friedrich M, Grootes PM, Guilderson TP, Hajdas I, Heaton T, Hogg AG, Hughen KA, Kaiser KF, Kromer B, McCormac FG, Manning SW, Reimer RW, Richards DA, Southon JR, Talamo S, Turney CSM, van der Plicht J, Weyhenmeyer CE. 2009. IntCal09 and Marine09 radiocarbon age calibration curves, 0-50,000 years cal BP. Radiocarbon 51(4): 1111-50.

Rohner C, Ward D. 1999. Large mammalian herbivores and the conservation of arid Acacia stands in the Mid- dle East. Conservation Biology 13(5):1162-71.

Vose RS, Schmoyer RL, Steurer PM, Peterson TC, Heim R, Karl TR, Eischeid JK. 1992. The Global Historical Climatology Network: Long-Term Monthly Temperature, Precipitation, Sea Level Pressure, and Station Pressure Data. ORNL/CDIAC-53; NDP-041. 325 p. doi:10.3334/CDIAC/cli.ndp041.

Ward D, Rohner C. 1997. Anthropogenic causes of high mortality and low recruitment in three Acacia tree taxa in the Negev desert, Israel. Biodiversity and Conservation 6(6):877-93.

Wiegand K, Jeltsch F, Ward D. 2004. Minimum recruitment frequency in plants with episodic recruitment. Oecologia 141(2):363-72.

Zeide B. 1993. Analysis of growth equations. Forest Science 39(3):594-616. 